\title{
Die priesterskap van die gelowiges soos Calvyn dit gesien het
}

\author{
AD Pont \\ Universiteit van Pretoria
}

\begin{abstract}
The priesthood of all believers as seen by Calvin

The Lutheran thesis of the priesthood of all believers was also taken over by John Calvin. The position of this thesis in Calvin's theology is examined and it is shown that Calvin does not treat this thesis as a separate statement. A short introduction is given of the main points Calvin explores when he discusses the meaning of the thesis. In the end it is shown that Calvin developed the thesis of the universal priesthood in such a low-key form to preserve the order in the Church and the prime position of the preaching of the gospel.
\end{abstract}

\section{WOORD VOORAF}

Dit is vanjaar 'n besondere gedenkjaar vir prof dr FJ van $\mathrm{Zyl}$. Dit is met graagte dat ek aan die versoek voldoen het om 'n bydrae tot hierdie huldigingsbundel te maak.

My persoonlike aanraking met prof Van Zyl gaan terug na die jaar 1955 toe ek as jong predikant in Elsburg kon voordeel trek uit die wysheid, kennis en insig van my ouer kollega in Springs. Daarna was dit my voorreg om in die jare 1960 1978 saam met hom te werk in die teologiese opleiding terwyl ek ook vir 'n kort termyn saam met hom in die Kommissie van die Algemene Kerkvergadering, waarvan hy die onder-voorsitter was, kon gedien het. In al die jare was dit vir my 'n vrugbare en verrykende ervaring om gedagtes met die ouer kollega te wissel. Sy rustige geaardheid, sy groot teologiese kennis en sy oorwoë mening was altyd die moeite werd om van kennis te neem. Omdat ons beide die voorreg gehad het om ons lewe te slyt in die diens van die kerk, die gelowiges, het ek gedink om hierdie beperkte studie oor Calvyn se visie van die priesterskap van die gelowiges aan hom op te dra. Mag dit so wees dat prof Van Zyl nog lank en vrugbaar in sy dienswerk besig mag bly. 


\section{INLEIDEND}

Die saak van die priesterskap van die gelowiges, kom telkens na vore in die geskiedenis van die kerk vandat Luther dít, in sy stryd téen Rome, so skerp na vore gebring het. Dit was veral in sy geskrif $A n$ den christlichen Adel wat Luther dié gedagte teenoor die Roomse klerikalisme na vore gebring het. Vir Luther lê die roeping tot priesterskap van die gelowige saam met die doop en elke gelowige is daarom 'n priester. Op die manier reken Luther af met die Roomse onderskeiding tussen clerus en leke en die Roomse opvatting dat die priester die ware kerk is (Eastwood 1960: 240).

In die Reformatoriese kerke het die gedagte van die priesterskap wél uitdrukking in die Confessio Helvetica posterior van 1566 gekry maar dit het nooit tot 'n selfstandige leerstuk ontwikkel nie. Dit het steeds gefunksioneer as 'n onderdeel van die kerk se leer oor die amp en soos die kerk-opvatting al meer in strukture gestol het, het die gedagte van die priesterskap van die gelowiges ook op die agtergrond geraak. Hoewel almal weet dat die kerk uit gelowige mense bestaan, het dit selfs in ons dae so geword dat die begrip die kerk gekorreleer word met die vergaderings van die ampte. Dit is, al is dit net 'n simptoom van slordige denke en spreke, tog merkwaardig dat selfs in ons Calvinistiese kerke die gewone, gelowige lidmaat in die kerklike gemeenskap geringer geag word as die predikant wat 'n studie van die teologie gemaak het of die ouderling en diaken wat tot 'n belangrike amp in die kerk geroep is.

Aan die ander kant is daar óók die gedagte dat juis in ons dae die priesterskap van die gelowiges wếr uitgebou moet word en die 'gewone gelowiges' al meer ingetrek moet word in die dienswerk van die kerk in die wêreld. In 'n sekere sin hang dit weer saam met die hele ver- indiwidualisering van ons gemeenskap en die eis van die moderne antroposentriese denke dat die gelowige iets in die kerk moet doen. Menslike doenigheid en besig-wees $66 \mathrm{k}$ in die kerk word baie hoog aangeslaan en bevorder. Dit is juis in hierdie soort denke, waar Kohlbrügge se korrektief negeer word, waar die hele saak van die priesterskap van die gelowiges oorbeklemtoon en daarom ook skeefgetrek word. Daarom kan dit miskien goed wees om en net vas te stel waar die leer van die priesterskap van die gelowiges in die geheel van die leer van die kerk ingepas word. Dit behoort 'n aanduiding te gee van enersyds die gewig wat aan dié leer gegee kan word en terselfdertyd sal dit 'n aanduiding wees van die samehange van dié leer. Dit is veral van belang in die Reformatoriese teologie waar die vermoëns van die mens, ook in sy verhouding met God oor die algemeen nie so hoog aangeslaan word nie. 


\section{DIE POSISIE VAN DIE LEER OOR DIE PRIESTERSKAP VAN DIE GELOWIGES}

As die posisie van die leerstuk in die Lutherse teologie tersyde gelaat word (kyk egter AD Pont 1964: 4-6) dan is dit allereers van belang om te sien hoe Calvyn dié saak hanteer. As gelet word op die uitspraak van Niesel (1957: 202) dan sou mens kan dink dat die leer van die priesterskap van die gelowiges géen rol by Calvyn speel nie. Maar as gelet word op die Institusie dan word daar tog daarna verwys.

Die eerste maal wanneer die begrip by Calvyn in die Institusie voorkom, is wanneer Calvyn die saak behandel waarvoor Jesus Christus deur God die Vader na ons wereld gestuur is. In die behandeling van die triplex munus van Christus (Institusie II.15) waar hy die taak van Christus ter wille van ons skerp beklemtoon. kom die saak van die priesterskap van die gelowiges 'n oomblik na vore (II.15.6). 'n Oomblik vantevore (II.7.1) het hy die saak ook terloops genoem en verwys hy na 1 Petrus 2:9 en sien hy die priesterskap van die gelowiges as 'n uitvloeisel van Christus se priesterlike taak wat $\mathrm{Hy}$ ter wille van ons volvoer het.

Die saak van die priesterskap van die gelowiges word ook weer 'n enkele maal genoem as Calvyn die saak van die sleutelmag van Petrus bespreek (III.4.14), en dan kom dit weer na vore in die ekklesiologie ook rondom die sleutelmag (IV.7.4) en dan weer wanneer die Roomse mis bespreek word (IV.18) en die ander sakramente (IV.19.28). Die opvallende by Calvyn is, as so na die plek van die priesterskap van die gelowiges gekyk word, dit nie in bespreking gebring word wanneer die amp ter sake is nie en dat dit ook nie teenoor die amp gestel word nie, maar veel eerder saamhang met 'n bespreking van die lewe van die gelowige.

Dat in die calvinistiese teologie die amp en die priesterskap van die gelowiges nie in mekaar se verlengde lê nie, blyk duidelik uit die Confessio Helvetica posterior van 1566, Artikel 18 waar in hoofsaak oor die amp gehandel word. Daar word gestel (Schaff 1919: III.281):

Diversissima ergo inter se sunt sacerdotium et ministerium. Illud enim commune est Christianis omnibus, ut modo diximus, hoc enim non item.

Interessant genoeg word die saak van die algemene priesterskap van die gelowiges nié eksplisiet in die Nederlandse Geloofsbelydenis genoem nie hoewel dit in Artikel 27 geïmpliseer word. Dieselfde kan van die Heidelbergse Kategismus gestel word. Dit is dus duidelik dat hierdie saak in die Calvinistiese kerke van die $16 \mathrm{e}$ eeu nie juis 'n selfstandige saak was nie. Dit is nie onbelangrik nie en moet nie uit die oog verloor word as oor hierdie saak gehandel word nie. 


\section{DIE INHOUD VAN DIE LEER BY CALVYN}

Die saak van die priesterskap van die gelowiges word deur Calvyn gekoppel aan sy uitleg van die drievoudige dienswerk van Christus (munus triplex) en dit is opvallend in sy bespreking van hierdie saak dat Calvyn nêrens praat van die indiwiduele gelowige as 'n alleen-staande figuur nie. Wat dit betref, is Calvyn 'n tipiese 16e eeuer want hy ken nie ons beheptheid met die enkeling, sy regte en vryhede nie. Calvyn draai die saak om en stel dat in die herskepping juis daarom gaan dat God se orde weer herstel sal word en dit beteken dat God die mens roep, aan hom die geloof gee en dan in-rangskik in sy orde en plan.

Dié saak stel Calvyn baie duidelik wanneer hy argumenteer dat die God die gelowiges tot kinders aangeneem het op grond van die priesterlike versoening wat Jesus Christus bewerk het (Inst II.7.1). Juis in die roeping en die aanneming word die priesterskap van die gelowiges 'n werklikheid. Dit is iets wat die mens ontvang en wat hy nie verdien nie en so hang die priesterskap van die gelowiges 66k saam met die leer van die uitverkiesing (Eastwood 1960: 72).

Om egter terug te keer tot die triplex munus van Christus en die gevolge daarvan vir die gelowiges, is dit belangrik om daarop te let dat by Calvyn die priesterskap van die gelowiges afhanklik is van en verbind is aan die priesterskap van Christus, die enigste Middelaar.

Om die priesterskap van die gelowiges verder te verklaar, bespreek Calvyn dit in verband met die sleutelmag wat die Roomse priesterskap sien as die sentrum van hulle amp. Calvyn argumenteer dan dat die Roomse hiërargie 'n voorreg wat aan die kerk as geheel, die gelowiges dus, gegee is op 'n onregmatige manier oorgeneem het (Inst IV.6.3-4). Calvyn wys dan daarop dat die Roomse teoloë sê dat Christus aan Petrus die hoofskap van die kerk gegee het toe Hy aan hom die sleutelmag gegee het 'maar', stel Calvyn dan (Inst IV.6.4), 'wat Hy toe aan een belowe het, skenk Hy op 'n ander plek aan al die ander dissipels saam en gee dit hulle as 't ware in die hand.' Daarmee beklemtoon Calvyn dat die sleutelmag die voorreg van die Christusgelowige gemeenskap is wat in die naam van Christus byeen is. Calvyn se hele argument draai om die argument dat deur die geloof in Christus, deur die deelhê aan Christus word die gelowiges ook deelhebbers aan die priesterskap van Christus. Juis met hierdie stelling gee Calvyn aan die priesterskap van die gelowiges sy diepste grond en word dit duidelik dat die gedagte van die priesterskap van die gelowiges uitdrukking wil gee aan 'n geestelike voorreg, 'n persoonlike roeping en 'n verantwoordelikheid. 'n Geestelike voorreg omdat die gelowige danksy die priesterlike offer van Christus, nou direk toegang het tot God, 'n persoonlike roeping en verantwoordelik teenoor die gemeenskap van die kerk in wie se midde die gelowige deur die viva vox evangelii die geloof ontvang het. Daarby 
word dit duidelik dat 'die wêreld' die plek is waar die gelowige, saam met die ander, sy priesterskap (moet) uitleef. Belangrik is dit om daarop te let dat die deelhê aan die priesterskap van die gelowiges nie geskied deur middel van of met die hulp van 'n offerende priesterdom nie, maar deur die regverdiging deur die geloof alleen. Hierdie geloof wat die sondaar regverdig is 'n genadegawe van God wat voorafgaan aan 'n menslike keuse of doenigheid.

Die priesterskap van die gelowiges as 'n korporatiewe priesterskap waaraan almal in die gemeente deel het, is 'n hoë roeping want aan die korporatiewe priesterskap word die sleutelmag toevertrou en nie net aan enkele ampsdraers nie. Buitendien is die ampsdraers geroepe gelowiges wat met 'n verdere roeping en opdrag belas word en as sodanig staan hulle nie bokant die gemeente nie, maar in die midde van die gemeente. Die ampsdraers is immers geroepe diensknegte van Christus en van die gemeente en nooit heersers van die gemeente, die korporatiewe priesterskap nie.

In hierdie verband kan verwys word na 'n gebed van Calvyn waarin hy die saak van die priesterskap van die gelowiges na vore bring. In die gebed stel hy (Eastwood 1960: 85):

\begin{abstract}
Almagtige God
Aangesien $U$ dit so beskik het om ons as priesters aan te neem, en aangesien $U$ ons gekies het toe ons nie alleen sondig was nie maar ook onheilig en vreemd van elke vorm van heiligheid was, en aangesien $U$ ons aan $U$ toegewy het deur u Heilige Gees, gee dat ons onsself as 'n heilige offerande aan $U$ kan offer. Gee dat ons voortdurend ons diens en ons roeping in gedagte sal hou en dat ons onsself van harte sal toewy aan $U$ diens sodat ons ons arbeid en ons pogings aan $\mathrm{U}$ kan voorlê en sodat u naam deur ons verheerlik kan word. Gee dat dit duidelik sal word dat ons ingeënt is in die liggaam van u eniggebore Seun. Aangesien Hy die hoof, enigste en voortdurende priester is, gee dat ons deelnemers mag wees van daardie priesterskap waardeur $\mathrm{U}$ in u goedheid $\mathrm{Hom}$ vereer het, sodat $\mathrm{Hy}$ ons as deelnemers aan Homself sal beskou, sodat u naam so voortdurend groot gemaak sal word sowel deur die hele liggaam as deur die Hoof.
\end{abstract}

So word die verdere dimensie van die priesterskap van gelowiges by Calvyn duidelik. As priesters bring die gelowiges offerandes maar omdat die gelowiges alleen priesters in Christus kan wees, daarom kan hulle ook nie anders offers bring as in die naam van en deur die genade van Christus nie. 
Die vraag is nou watter offerandes kan die gelowiges as priester bring. Ook hier bestaan daar by Calvyn geen onduidelikheid nie en as hy die Roomse offergedagte bespreek, behandel hy ook die offers wat die koninklike priesterdom, die gemeente van Christus moet bring. Dié offerandes dui Calvyn aan (Inst IV.18.16):

... al die pligte van die liefde waardeur ons, as ons dit aan die broers bewys, die Here self in sy lidmate eer; vervolgens al ons gebede, lofen dankseggings en alles wat deur ons in diensbaarheid aan God, gedoen word ....

Hierdie soort offerandes is nie daar om God se toorn te stil nie, ook nie om vergiffenis van die sonde te kry nie en ook nie om geregtigheid te verdien nie, maar dit word uitsluitlik gedoen om God te verheerlik en groot te mak. Want hierdie offerandes kan nie vir God aangenaam en aanneemlik wees nie tensy dit gedoen word deur sulke gelowiges aan wie Hy reeds die vergiffenis van die sonde gegee het, om ' $n$ ander rede met Homself versoen het en daarom reeds van skuld vrygespreek het.

Die belangrike wat Calvyn in hierdie verband beklemtoon is dat die offers wat die priesterskap van gelowiges bring, nooit anders as deur die Middelaar geskied nie. Met ander woorde hier is nie meer sprake van priesters wat 'n offer bring nie want '... Christus wat onsterflik is, is die enige en ewige priester' (Inst IV.18.2) soos Calvyn dit stel (Inst IV.18.17):

Want ons verskyn nie met ons gawes voor God sonder 'n middelaar nie. Christus is ons middelaar deur wie ons onsself en wat aan ons behoort, aan die Vader offer. Hy is ons hoëpriester wat, nadat $\mathrm{Hy}$ in die heiligdom van die hemel ingegaan het, vir ons die toegang moontlik maak. Hy is die altaar waarop ons ons gawes neerle sodat ons in Hom alles kan probeer wat ons probeer. Hy is dit wat ons konings en priesters vir God sy Vader gemaak het (Op 1:6).

As Calvyn die priesterskap van die gelowiges omskryf dan skryf hy aan die geestelike priesterdom al die kenmerke en dienste van Ou-Testamentiese priesters toe: 
- hulle is heilig want hulle is deur God uitgekies (1 Pet 1:2, 15);

- hulle is besprinkel met die offerbloed omdat hulle Christus se offer aanvaar het (Heb 12: 24);

- hulle is met suiwer water in die doop gewas (Heb 10: 22);

- hulle is gewy deur die oplegging van hande (Heb 6: 2);

* hulle is gesalf ( $1 \mathrm{Joh} 2: 20)$;

* hulle is onderrig soos hulle ook moet onderrig (1 Joh 2: 27);

- hulle offer offerandes, goeie werke, gebede en lof (Rom 12:1; Ef 5:2; Heb $4: 16 ; 13: 15)$.

So word dit duidelik dat by Calvyn die priesterskap van die gelowiges beteken dat die gelowiges in en deur Christus voortdurend geestelike offers moet bring om so God te verheerlik.

Die opvallende van Calvyn se opvatting is dat hy in die Institusie die priesterskap van die gelowiges behandel nadat hy reeds uitvoerig oor die amp gehandel het. Dit gebeur vanweë verskillende oorwegings waarvan die belangrikste seker is dat Calvyn besonder daarop gesteld is dat alles ordelik moet geskied en dat niemand ' $n$ amp of diens in die kerk mag beoefen as hy nie behoorlik daartoe geroep is nie (Inst IV 2.10). Calvyn is skerp gekant teen enigiets wat lyk na 'n charismatiese ampsopvatting juis omdat hy so 'n hoë premie op die regte verkondiging van die evangelie plaas.

\section{DIE SWAARTEPUNT IN DIE KERK}

Die byna algemeen aanvaarde standpunt van die Calvinistiese kerke oor wáár die swaartepunt in die lewe van die kerk lê, word nogal netjies verwoord deur die Confessio Helvetica posterior Artikel 18 wat stel (Schaff 1919: III: 278).

Deus ad collingendam vel constituendam sibi Ecclesiam, eandemque gubernandam et conservandam, semper usus est ministris, iisque utitur adhuc, et utetur porro, quoad Ecclesia in terra furit. Ergo ministrorum origo, institutio et functio vetustissima et ipsius Dei, non 
nova aut hominum est ordinatio.

Dieselfde standpunt word deur Calvyn self'gehuldig sonder dat hy daarmee 'n domineeskerk wil bou, want in Calvyn se dinamiese kerkopvatting is so iets nie moontlik nie. Dit word egter wel 'n moontlikheid waar die organisatoriesstrukturele in die liggaam van die kerk oorheersend word. Dit word, in die verbygaan, nogal effektief geillustreer deur ons Algemene Kerkvergadering. Die sinodale vergadering wat begin as 'n kerkraadsinode in 1853 het as gevolg van onnadenkendheid, gewoonte en miskien selfs bygelowigheid ' $n$ predikantevergadering met die toevoeging van kerkraadslede geword. Soos die saak tans staan, word die vergadering gevorm deur die somtotaal van almal wat as dienaar van die Woord aangedui word saam met ongeveer $4,1 \%$ van die totale getal ouderlinge. So het dit die enigste vergadering van die ampte in ons kerk geword waar die getal ouderlinge op die vergadering oorheers word deur die getal dienaars van die Woord. Die interessante is dat hierdie status quo, wat 'n bespotting maak van ons presbiteriaal-sinodale kerklike organisatoriese erfenis, so gehandhaaf word omdat dit gesien word as ' $n$ vergadering wat breed-verteenwoordigend moet wees. Hierin word duidelik hoe 'n stuk Calvinistiese erfenis deur verwaarlosing, skeefgetrek kan word. Want dit is natuurlik so dat Calvyn aan die dienaar van die Woord 'n sekere primaat verleen want, soos Calvyn dit stel (Inst IV.3.2): praecipuum esse nervum quo fideles in uno corpore cohaerant, ofwel die dienaar van die Woord is die belangrikste senuwee waardeur die gelowiges in een liggaam verbind is. Calvyn is dan ook oortuig dat sonder goeie dienaars van die Woord sal die kerk gou in duie stort. Soos hy dit stel in die Kommentaar op Jeremia 3:15: 'Die toestand van die kerk kan nie behou word as daar nie getroue herders is wat die pad na redding aandui nie ... wanneer die kerk sonder goeie leraars moet klaarkom, stort alles in duie.' Die dienaar van die Woord wat in diens van God staan is van uiterste belang want 'die kerk van God word nie alleen in die lewe geroep deur middel van heilige en vroom herders nie, maar die lewe van die kerk ... word ook deur hulle versorg, gevoed en bevestig tot aan die einde (Calvyn se kommentaar op Jer 3: 15).

Tog wil Calvyn nie daarmee aan die dienaar van die Woord as mens so ' $n$ voorrang gee nie maar wel aan sy dienswerk (Inst IV.8.2) maar terselfdertyd stel Calvyn in sy kommentaar op 2 Korintiërs 13: 8: 'Hierdie gedeelte moet sorgvuldig in ag geneem word, want dit beperk die mag wat die herders van die kerk sal hê en terselfdertyd stel dit die grense daarvan vas naamlik dat hulle diensknegte van die Waarheid sal wees ... in onderworpenheid aan die Waarheid.' So is die dienaar van die Woord 'n dienskneg van Christus en ook die dienskneg van die gelowiges ofwel 
die kerk. As die dienaar van die Woord sy dienswerk reg verrig dan word dit deur sy dienswerk duidelik dat in laaste instansie dit Christus self is wat as hoof van sy liggaam, sy kerk regeer (Inst IV.3.1).

Juis so word dit weér duidelik dat die amp as dienswerk wel teenoor die priesterskap van die gelowiges staan en terselfdertyd omring die priesterskap die amp en ondersteun dit. Die dienswerk van die amp is daar ter wille van die gelowiges en saam word ampsdraer en gelowiges geroep om tot eer van God te lewe, daarin gelei, geleer en gerig deur die verkondiging van die evangelie.

Die swaartepunt in die kerk lè dus dárin dat die dienswerk van die dienaar van die Woord in ewewig met die priesterskap van die gelowiges moet saamwerk om van die gemeente 'n lewende getuie van Jesus Christus in die wêreld te wees.

\section{SAMEVATTEND}

Dit is van belang ter wille van die orde van die kerk, die dienswerk van die verkondiging van die Woord én die regte verstaan van die priesterskap van die gelowiges dat die sorgvuldige balans en die inhoude wat Calvyn aan die bogenoem. de begrippe gegee het, nie verwaarloos sal word nie. Die sogenaamde 'nood van die prediking' behoort ons nie daartoe te bring om die korporatiewe priesterskap van die gelowiges skeef te trek nie. Dit is natuurlik betreklik maklik om dit te doen omdat, vanweë die verindiwidualisering van die mens, die natuurlike verbondenhede in die gemeente al meer onder druk geplaas word. Dit is ' $n$ vraag of ons nog, soos dit in 'n volkskerk hoort, die gelowige huisgesin sien as die bousteen van die gemeente en dat die priesterskap van die gelowiges 'n korporatiewe begrip is waarvolgens almal saam hulle offers so moet bring dat die naam van God daardeur verheerlik word. Aan die ander kant lê daar $66 \mathrm{k}$ gevaar in om die verkondiging van die Woord deur die geroepe en bevestigde ampsdraer te depresieer en te probeer vervang deur allerlei georganiseerde doenighede van die lidmate. In hierdie verband is dit, ter wille van die balans noodsaaklik om tog weer kennis te neem van HF Kohlbrügge se skerp opmerkings oor te veel menslik 'doenighede' in die kerk. Miskien kan mens hier weer luister na Kohlbrügge se helder siening in sy Vragen en antwoorden tot opheldering en bevestiging van den Heidelbergschen Catechismus waar hy stel (bl 160):

Wat hebben wij over het algemeen omtrent het houden van de geboden Gods te bedenken? 
Dat wij daartoe geheel onbekwaam zijn, dat zulks echter niet aan de geboden, maar aan ons ligt. De Wet is heilig, zij moet niet alleen naar de letter, maar naar den geest gehouden worden; wij daarentegen zijn vleeschelijk, verkocht onder de zonde. Dat moet bij ons vaststaan, dat wij volstrekt in overeenstemming met de Wet moeten zijn, en juist daarom hebben wij ons aan Christus, hebben wij ons aan $\mathrm{Zijne}$ genade vast te houden, en zoo zullen wij door Zijnen Geest, naar Zijne belofte, wandelen aan $Z$ ijne hand en naar $Z$ ijne raad, in eene door Hem vervulde Wet, zoo dat wij daarbij zondaars blijven en alleen $\mathrm{Zijne}$ heiligmaking roeme.

As daar dus oor die priesterskap van die gelowiges nagedink word, dan is Calvyn èn die Reformatoriese tradisie ' $n$ uitnemende gids om ons daarvoor te bewaar dat ons 'n regte balans handhaaf. Dit gaan in die priesterskap van die gelowiges om die geestelike offerandes wat die priesterdom in Christus moet bring tot eer van God. Geestelike offerandes in Christus - daarom gaan dit en wat dit beteken leer die Woord van God ons. Uiteindelik kom ons altyd weer daarby terug en daarom kan die saak afgesluit word met 'n woord van Luther:

In der Kirche soll man nichts mit grösseren Sorgfalt betreiben als das heilige Evangelium, da ja die Kirche nichts Kostlicheres und Heilsameres hat.

\section{Literatuurverwysings}

EASTWOOD, C 1960. The priesthood of all believers. London: The Epworth Press. NIESEL, W 1957. The Theologie Calvins. Zürich: EVZ-Verlag.

PONT, AD 1964. 'n Dogmenhistoriese skets van die leer van die algemene priesterskap van die gelowiges. HTS 20/1.

PONT, AD 1984. Die priesterskap van die gelowiges en die ampte in die kerk. HTS $40 / 4$.

SCHAFF, P 1919. The creeds of Christendom, Vol III. New York: Harper and Brothers. 